\title{
The Role Of Higher Education In Personal Relationships
}

Amanda Lemoine, Southeastern Louisiana University, USA

Alexandra Mayer, Southeastern Louisiana University, USA

Arletta Gordon, Southeastern Louisiana University, USA

Melanie Johnson, Southeastern Louisiana University, USA

Michael C. Budden, Southeastern Louisiana University, USA

\begin{abstract}
The roles within personal relationships have evolved throughout the years. What was once a "traditional" role within a household is now considered outdated and old-fashioned. These roles have been influenced by many factors, one of those being higher education. A study was conducted to examine how those roles have been influenced by higher education. In the late 1940's, many U.S. women stayed home, raised their children and did not work outside the home unless there was a missing male figure to provide for the family. Although women may have wanted to venture into the workforce, it wasn't widely accepted. However, a Census Bureau study in 1948 found that 17 million women were in the paid labor force (Walker 1998).
\end{abstract}

Keywords: higher education; marriage; life goals; changing roles; lifestyles

\section{INTRODUCTION}

n the 1950's, it was widely understood that women were to get married, raise children, and support the husband in his chosen profession. The woman was a nurturer and the man's main priority was to be the provider. Men were the ones pursuing higher education and career paths (Lige 2003).

By the end of the 1960's, higher education enrollment was on the rise as baby boomers emerged as a force with which to reckon. Higher education enrollments continued to rise throughout the 1960's.

Although paid significantly less (about 45 percent) than men, the number of women in the workforce during the 1970s increased significantly. However, the gap in pay may have been attributed to the fact that many women pursued female-intensive careers, such as teaching, nursing, and administrative assistant positions. Legalization of birth control in 1965 caused a significant number of women to seek careers first rather than have children (Piccinino and Mosher, 1998). The Women's Education Equity Act, which encouraged full educational opportunities for women and girls, and The Pregnancy Discrimination Act, which banned employment discrimination against pregnant women, encouraged women to seek career options.

The number of women pursuing bachelor's degrees in business in the early 1980s were 45.1 percent compared to only 9.1 percent a decade earlier. Educational attainment of women equaled that of men (Kopka and Korb, 1998).

In the 1990's, the median age in which women in the United States married rose to 25 years of age. The largest decline of birth rates in the history of the United States occurred between 1990 and 1999. The number of women receiving degrees in the 1990's finally surpassed the number of men (Hamilton and Ventura 2006).

By the $21^{\text {st }}$ century, the number of women enrolled in higher education reached an all time high and continues to surpass the number of male students. Socio-demographic implications are strong. According to Carvel (2003), women graduates are 50 percent more likely than non-graduates to remain childless. Research indicates that 
younger women are marrying much later than they did a decade ago, and many are single into their 30s (Loane and Horin 1998).

So, how have the roles of men and women changed from the 1940's to the present day? How has higher education influenced gender roles, and will it continue to influence these roles? These are questions that were addressed in this study.

\section{METHODOLOGY}

Data was obtained through a convenience survey in the summer of 2010. The convenience survey was conducted on a campus in the Southeast United States. Two-hundred-fifty-one surveys were distributed and collected. Due to missing data, 16 surveys were unusable. The data collected included questions about marital preference, a series of questions about the ideal spouse, demographic questions, and the primary reason for pursing a college degree. Specific objectives included determining:

- $\quad$ The role age plays in relationships

- $\quad$ How the "traditional" male and female roles are changing

- The importance of higher education in relationships

- To what extent higher education influences career decisions

- Whether the pursuit of higher education is causing life goals (buying a home, getting married, or having children) to be delayed

- $\quad$ The primary reason one pursues a higher education

\section{FINDINGS}

\section{Does age Play A Role in Relationships?}

Of those surveyed, 37.7 percent would want their spouse to be the same age as themselves. Following close behind, 36.4 percent of participants would want their spouse to be up to five years older than themselves. A smaller percentage would want their spouse to be up to five years younger than themselves, and very few wanted their spouses to be either five years + older or younger. For the most part, results in Table 1 indicate that participants want a spouse around the same age as themselves.

Table 1

What age would you prefer your spouse to be?

\begin{tabular}{llcc}
\hline & & Frequency & Percent \\
Valid & 5yrs+ younger than you & 4 & 1.8 \\
& Up to 5 yrs younger than you & 36 & 15.8 \\
The same age as you & 86 & 37.7 \\
Up to 5 yrs older than you & 83 & 36.4 \\
5yrs+ older than you & 19 & 8.3 \\
Total & 228 & 100.0 \\
\hline
\end{tabular}

\section{How are the "Traditional" Male and Female Roles Changing?}

There have been noticeable changes in gender roles. According to the survey, a majority of males (52 percent) and 49 percent of females thought that women should be the primary caregiver to a child. A little more than one-forth of males and 32 percent of women felt that children should attend a daycare center or have a nanny.

The majority of males ( 85 percent) and 78 percent of women agreed that both partners should do housework. Very few - 12 percent of men and 20 percent of women - felt that women should do the majority of the housework. Not surprisingly, a mere three percent of the participants surveyed felt that men should take care of the housework. 
The results of the question concerning who should make more money in a marriage was interesting. A small percentage - 13 percent of men and 14 percent of women - said that men should make more money in a marriage. An overwhelming majority ( 86 percent of males and females) felt it did not matter which spouse made the majority of the income.

\section{How Important is Higher Education for Yourself and Your Spouse?}

Most respondents desired a higher level of education for themselves than their spouses. Of the 233 students surveyed, 27.9 percent desire a Bachelor's degree for themselves. The majority of students ( 60.9 percent) desire a Masters. On the other hand, the majority of students (51.3 percent) desire only a Bachelor's degree for their spouses. Most students thought it important for their spouses to have a college education.

\section{To What Extent will Higher Education Influence Career Decisions?}

As shown in Table 2, the majority of respondents ( 89.3 percent) would most likely continue his or her career if he or she were to marry a wealthy individual after graduation. Both men and women had similar views.

Table 2

If you were to marry a wealthy individual after graduation, what is the likelihood that you would continue your career?

\begin{tabular}{llcc}
\hline & & Frequency & Percent \\
Valid & Unlikely & 3 & 1.3 \\
& Unsure & 22 & 9.4 \\
& Likely & 208 & 89.3 \\
& Total & 233 & 100.0 \\
\hline
\end{tabular}

\section{Is the Pursuit of Higher Education causing Life's Goals to be pushed to the Back Burner?}

According to our research, three-quarters of those surveyed believed that one should wait to marry until after graduating with a college degree. Similarly, 79.4 percent believed one should wait to have children. The majority of those surveyed (73.6 percent) believed one should wait to purchase a home until after graduation. It would appear respondents believe that obtaining an education is desirable before pursing life's goals, such as getting married, having children, and buying a home.

\section{What is the Primary Reason to Pursue A Higher Education?}

Table 3 reflects that of those surveyed, seeking a career was the biggest reason (36 percent) to pursue a college degree. At 33.8 percent, potential income was the second reason to pursue a college degree. Still very important, 30.2 percent of those surveyed reported seeking higher education for self-fulfillment.

Table 3

What is the primary reason you are pursuing a college degree?

\begin{tabular}{lcc}
\hline & Frequency & Percent \\
Money & 75 & 33.8 \\
Career & 80 & 36.0 \\
Self-fulfillment & 67 & 30.2 \\
Total & 222 & 100.0 \\
\hline
\end{tabular}

\section{LIMITATIONS}

The results of this study may not be generalized as it was a convenience sample conducted at one university in the southeastern U.S. However, it does give insight into the current perception and 


\section{CONCLUSION}

The roles of men and women have evolved over the years. It can be seen from this study that neither women nor men hold the traditional values as those of the past. Women are no longer viewed as simply a "stay at home mom" and men are no longer expected to be the primary bread winner. Although the majority of participants decided the mother staying home to care for an infant was important, many still agreed upon available child care options, such as daycare centers, a nanny, or even grandparents. Roles are being equally divided based on education and earning power, rather than gender, to determine the best outcome for a family. The majority are waiting to finish their higher education goals before pursuing marriage, children, and owning homes. However, those within the ages of 19 and 32 were more likely to pursue starting a family and owning their own home than their older and younger counterparts. Ironically, those within that same age group are the ones wanting to pursue the highest level of education. Putting these two answers together, those that wouldn't want to wait to start their family and buy a home while pursuing the highest level of degree possible have a very long road ahead of them. This is consistent with other studies showing age-related differences in regards to career decisions. Another study revealed that older graduates made different career decisions than their younger counterparts (Saunders and Stivason 2010).

Not only does it appear that higher education is important for one's-self, it is important for the majority for their spouse to pursue an education higher than a high school degree. It appears people have higher expectations for themselves as opposed to their spouse. For instance, a person may desire an Associate's or Bachelor's degree for their spouse, but they aspire to obtain a Masters degree or higher for themselves.

Several factors influence people's decisions toward higher education and their relationships with a spouse. In general, women's roles, with respect to higher education and career goals, have changed over the past 70 years. While roles have changed, those that were affected by the change of "traditional roles" in the early 1940's and on, work side-by-side with those that are currently pursuing career goals after higher education. For instance, Delvechio (2009) investigated the beliefs that Baby Boomers and Generation X enter the workforce with different attitudes.

While women used to fight for the right to even attend college, they are now pursuing college degrees in numbers exceeding their male counterparts. The "traditional" role of a woman staying home and tending house has moved to the pursuit of higher education and there has been an increase of women in the work force. "Mr. Mom" is no longer just a movie title; it is becoming more commonly accepted.

\section{AUTHOR INFORMATION}

Amanda Lemoine is an MBA student with an undergraduate degree in Marketing. Her research interests include Marketing, higher education, and ethics.

Alexandra Mayer is an MBA student with a background in business administration. Her research interests include cultural influences and international management.

Arletta Gordon is an MBA student with a background in kinesiology. Her research interests include education and health care administration.

Melanie Johnson is a first-year law student. Her research interests include education and law.

Michael C. Budden is the Mayfield Professor of Marketing at Southeastern. His research interests include business education, supply chain, international issues and law.

\section{REFERENCES}

1. Carvel, J. (2003, April 25). Graduates less likely to bear children. The Guardian (London), p. 11. Retrieved July 6, 2010.

2. Del Vecchio, S. (2009, September/ October). Baby Boomers And Generation X Industrial Salespeople: Generational Divide Or Convergence? Journal of Applied Business Research, 25(5), pp. 69-84. 
3. Hamilton, B. \& Ventura, S. (2006). Fertility and abortion rates in the United States, 1960-2002.

International Journal of Andrology, 29(1), 34-45. doi:10.1111/j.1365-2605.2005.00638.x.

4. Kopka, T. \& Korb, R., National Center for Education Statistics (ED), W., \& National Inst. on

Postsecondary Education, L. (1996). Women: Education and Outcomes. Statistical Analysis Report.

Retrieved from ERIC.

5. Lige, T. (2003, June). Men as nurturers: Journey to completion. www.alive.com, 41-44. Retrieved July 6, 2010.

6. Loane, S. \& Horin, A. (1998, April 20). Most still tie the not, but much later: Special report Australian women the vital statistics. Sydney Morning Herald, p. 4. Retrieved July 6, 2010.

7. Meyer, J. W., Ramirez, F. O., Rubinson, R. \& Boli-Bennett, J. (1977). The world educational revolution, 1950-1970. Sociology of Education, 50(4), 242-258.

8. Piccinino, L. \& Mosher, W. (1998). Trends in Contraceptive Use in the United States: 1982-1995. Family Planning Perspectives, 30(1), 4-46. Retrieved from Academic Search Complete.

9. Saunders, G. \& Stivason, C. (2010). How are your graduates doing? Do they still love you? Contemporary Issues in Education Research, 3(5), 9-19.

10. Walker, N. A. (1998). Women's Magazines (63). New York: Bedford/St. Martin's. 
NOTES 